Ks. Jan Klinkowski

\title{
Kobiety w „szkole” Jezusa i popaschalnej wspólnocie oraz ich różne modele życia i zaangażowania w ewangelizację
}

Jezus zgromadził wokół siebie wspólnotę uczniów, z której wybrał grono Dwunastu. Ale w Jego najbliższym otoczeniu znajdowały się także kobiety, które odegrały znaczącą rolę na drogach ewangelizacji. Jednak włączenie ich w ten proces wymagało przekroczenia wielu barier kulturowych, społecznych i religijnych. Jezus próbował przezwyciężyć starotestamentowe poczucie sacrum, na straży którego stały przepisy rytualnej czystości. Polemizując $z$ faryzeuszami i uczonymi w Piśmie na temat znaczenia przepisów dotyczących spożywania posiłków, wyjaśniał: „Nic nie wchodzi z zewnątrz w człowieka, co mogłoby uczynić go nieczystym; lecz co wychodzi z człowieka, to czyni człowieka nieczystym"1 (Mk 7,15).

I dalej: „Z wnętrza bowiem, z serca ludzkiego pochodzą złe myśli, nierząd, kradzieże, zabójstwa, cudzołóstwa, chciwość, przewrotność, podstęp, wyuzdanie, zazdrość, obelgi, pycha, głupota" (Mk 7,21-22).

Przezwyciężając segregację ludzi ze względu na spożywane potrawy, Jezus postawił wszystkim jednakowe kryteria moralne.

1 Cytaty biblijne za: Biblia Tysiąclecia. Pismo Święte Starego i Nowego Testamentu, wyd. 5, Poznań 2003. 
Podobnie przezwyciężył bariery, które dyskryminowały kobiety z powodu ich miesięcznego krwawienia i czyniły je nieczystymi. Pozwolił się dotknąć kobiecie, która od dwunastu lat cierpiała na upływ krwi, a więc społecznie była izolowana (por. Mk 5,25-34; Mt 9,20-22; Łk 8,43-48). Jej uzdrowienie stało się symboliczne, bo przywróciło ją do życia społecznego ${ }^{2}$.

Chrześcijaństwo nie tylko przezwyciężało podziały między mężczyznami i kobietami na drodze zbawienia, ale nadało tym drugim nową pozycję we wspólnocie wiary, gdzie stały się sługami słowa - „prorokiniami”, usługującymi wspólnocie i potrzebującym - „diakonisami”. Wraz z grupą „wdów” wszystkie wypełniały czas modlitwą, która z pewnością była zakotwiczona w tradycji modlitewnej Starego Testamentu. Ta wzrastająca pozycja kobiet we wspólnocie Kościoła wynikała z relacji, które zbudował Jezus, tworząc pierwszą wspólnotę wiary. W tych relacjach należy szukać inspiracji do budowania pozycji kobiety we współczesnym Kościele.

\section{Maria Magdalena - Apostołka Apostołów}

Wielką postacią pierwotnego chrześcijaństwa była Maria Magdalena, której została powierzona zaszczytna funkcja zwiastunki zmartwychwstania Jezusa (por. J 20,1-18). W tradycji nazywana jest Apostołką Apostołów ${ }^{3}$, bowiem to jej wiara w zmartwychwstałego wyprzedziła wiarę uczniów ${ }^{4}$. Została zaproszona do

2 Por. J. du Mesnil, Kobiety Nowego Testamentu, tłum. M. Crofta, Poznań 2010, s. 43.

3 „W dzisiejszym rozumieniu apostołowie i Dwunastu to ta sama grupa; w czasie, kiedy pisali ewangeliści, słowo «apostołowie» miało znaczenie szersze niż obecnie, do grona tego zaliczano po prostu nauczycieli nowej wiary, być może też kobiety", P. Lisicki, Tajemnica Marii Magdaleny, Kraków 2014, s. 80.

4 Por. R. Burnet, Maria Magdalena. Od skruszonej grzesznicy do oblubieńcy Jezusa, tłum. A. Kuryś, Poznań 2005, s. 40. 
posługi ewangelizacji podobnie jak pierwsi dwaj uczniowie, którzy spotkali Jezusa. Wówczas Syn Boży ich zapytał: „Czego szukacie?" (J 1,38) i był to początek ich drogi z Nim, a także zalążek wspólnoty apostolskiej. Analogicznie Jezus Zmartwychwstały pyta Marię: „Kogo szukasz?” (J 20,15) ${ }^{5}$. Jest to pytanie głębsze, bo Jezus pyta o relacje już nie przedmiotowe, ale podmiotowe. Początki budowania wspólnoty apostolskiej były oparte na relacji poznania i uwierzenia, a teraz potrzeba czegoś więcej. Czego? Osobistej więzi z Jezusem i to więzi miłości! Maria Magdalena, szukając Jezusa, udowodniła, że Go kocha, a Piotr będzie musiał potwierdzić miłość do Niego trzykrotnie słowami nad Jeziorem Galilejskim (por. J 21). Według ewangelisty Jana do bycia apostołem nie wystarczy wiara, ale potrzebna jest miłość do Tego, który przyniósł dar Ewangelii. W katalogach kobiet występujących w Ewangeliach Maria Magdalena pojawia się na pierwszym miejscu. Należała do grona „kobiet, które usługiwały gronu apostolskiemu ze swego mienia" (por. Łk 8,2-3), a więc prawdopodobnie wspierały je finansowo, dbały o szaty, przygotowywały posiłki. Przez miejsce pochodzenia jest przedstawiana jako Maria z Magdali ${ }^{6}$, co sugeruje, że nie była mężatką; być może przeżyła także swojego ojca i innych krewnych. Była więc kobietą żyjącą w pojedynkę, zdolną udzielać Jezusowi wsparcia

5 Por. C.M. Martini, Maria Magdalena naszq drogq̨ do Jezusa, tłum. W. Szymona, Kraków 2019, s. 129.

6 Jezus mógł nauczać w synagodze w Magdali. To jedna z najstarszych odkrytych synagog. Ruiny pochodzą z okresu między 50 rokiem przed Chr. a 100 rokiem po Chr. Synagoga miała powierzchnię 120m². Była otoczona kolumnami. Na jej podłodze odkryto mozaikę o geometrycznym wzorze. Wewnątrz przy ścianach pokrytych kolorowymi freskami stały kamienne ławy. W synagodze archeolodzy znaleźli wyjątkowo dobrze zachowaną stelę z rzadkim przedstawieniem menory, czyli siedmioramiennego świecznika, stojącego na trójkątnej podstawie, z dwiema amforami z prawej i lewe strony. Por. K. Wons, Uczennica i oblubienica. Lectio Divina z Mariq̨ Magdalenq, Kraków 2018, s. 28. 
z wdzięczności za to, co dla niej uczynił7. W jakim wieku była, gdy wyruszyła za Jezusem? Ikonografia przedstawia ją najczęściej jako młodą kobietę. Jednak grono kobiet podążających za Jezusem wydaje się być w porównywalnym wieku do Maryi, Jego Matki. Wśród kobiet pojawiających się przy Nim znajduje się Joanna, żona Chuzy (por. Łk 8,3; 24,10), bliżej nieokreślona Zuzanna, Maria, żona Kleofasa (por. J 19,15), Maria, matka Jakuba i Józefa (por. Mk 15,40.47; 16,1), matka synów Zebedeusza (por. Mt 20,20; 26,56), Salome (por. Mk 15,40). Skoro w większości są to kobiety zamężne, posiadające dzieci wchodzące w dorosłość, więc mamy chyba do czynienia z gronem niewiast około pięćdziesiątego roku życia. Święty Łukasz wspomina, że Marię Magdalenę opuściło siedem złych duchów (por. Łk 8,2), co również potwierdza św. Marek, wyjaśniając, że Jezus wyrzucił z niej złe duchy (por. Mk 16,9). Nie dziwi nas fakt zauważenia tego epizodu z życia Marii Magdaleny przez Łukasza, wszakże według tradycji był on lekarzem, a opętanie traktowano jako chorobę 8 . W przypadku Marii Magdaleny Łukasz wspomina jeszcze, że Jezus uwolnił ją od „słabości” (astheneia) (por. Łk 8,1), co należy rozumieć: od braku sił, niemocy albo jakiejś choroby ciała (por. Łk 13,11; J 5,5; 11,4) . Niektórzy dopatrywali się w tym jakichś zaburzeń seksualnych, inni doszukiwali się choroby psychicznej, jeszcze inni zwracali uwagę na depresję. Nie wiemy, jakie były przyczyny jej złego stanu, ale najwyraźniej w odczuciu otoczenia miała wewnętrzne problemy, które rzutowały na jej zewnętrzną postawę ${ }^{10}$. Możemy sobie zatem wyobrazić Marię Magdalenę ogarniętą złą mocą i wyalienowaną z życia społecznego. W Sta-

7 Por. A. Welborn, Maria Magdalena. Prawda, legendy i kłamstwa, tłum. K. Bednarek, Radom 2006, s. 23.

8 Józef Flawiusz wspomina Eleazara, który w obecności Wespazjana i jego świty leczył ludzi z opętania. Por. Józef Flawiusz. Dawne dzieje Izraela VIII, 45-48.

$9 \quad$ Por. K. Wons, Uczennica i oblubienica, s. 47n.

10 Por. C.M. Martini. Maria Magdalena naszq drogq do Jezusa, s. 70nn. 
rym Testamencie hebrajskie słowo szewa - „siedem” - ma ten

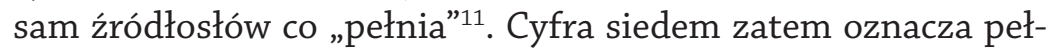
nię opanowania przez złe moce, co nie świadczy o jej grzeszności. W Nowym Testamencie stan opętania nie jest synonimem grzeszności. Jezus, uwalniając Marię Magdalenę spod władzy złych duchów, umożliwił jej powrót do życia w społeczeństwie. Co więcej, pozwolił jej dołączyć do grona niewiast usługujących Dwunastu. Wspólnota zawiązana wokół Jezusa była wyjątkowa, wszakże w ówczesnych czasach nie praktykowano, by kobiety podążały za nauczycielem i słuchały jego nauki. Maria Magdalena wytrwała przy Jezusie wraz z kilkoma niewiastami aż do ukrzyżowania (por. Mk 15,40-41; Mt 27,55; J 19,25; Łk 23,49). Wraz z innymi niewiastami uczestniczyła również w pogrzebie Jezusa (por. Mk 15,47; Mt 27,61; Łk 23,55). Gdy minął szabat i nastał świt pierwszego dnia tygodnia, kobiety udały się do grobu. Święty Mateusz pisze, że Maria Magdalena i druga Maria przyszły obejrzeć grób (por. Mt 28,1). Ewangeliści Marek i Łukasz wyjaśniają, że owe kobiety miały namaścić ciało Jezusa (por. Mk 16,1-2; Łk 24,1). Ewangelista Jan zauważa, że Maria Magdalena przybyła do grobu, gdy było jeszcze ciemno (por. J 20,1), a więc wyszła z domu w zasadzie, kiedy kobietom nie wolno było jeszcze tego robić. Ulice ówczesnej Jerozolimy były nieoświetlone i samotne wychodzenie o tej porze było nie wskazane. Ona jednak jak oblubienica z Pieśni nad Pieśniami nie potrafi już dłużej leżeć w łóżku, musi być u grobu wcześniej niż inne, nie licząc się z konwencjami grożącymi za złamanie zasad, zgodnie z którymi kobiety mogły wychodzić w czyimś towarzystwie, dopiero gdy się rozjaśniło. Maria wychodzi, bo już nie może dłużej wytrzymać, bo pragnie być blisko ciała Jezusa ${ }^{12}$. Z pewnością później dołączyły do niej, gdy już zaświtało, inne kobiety, co relacjonują pozostali ewangeliści. Jako pierwsze stały się świadkami Jezusowego zmartwychwstania, to im zostało

11 Por. K. Wons, Uczennica i oblubienica, s. 52.

12 Por. C.M. Martini, Maria Magdalena naszq drogq do Jezusa, s. 122. 
dane zobaczyć pusty grób, w którym złożono ciało Jezusa, i poinformować o tym fakcie uczniów (por. Mt 28,1-8; Mk 16,1-8; Łk 24,1-11) oraz doświadczyć obecności Zmartwychwstałego (por. Mt 28,9-10; Mk 16,9-11; J 20,11-18). Nie przypadkiem jeden z największych wrogów pierwotnego Kościoła, pogański filozof Celsus, w II wieku po Chr. wypomina, że wiara chrześcijańska powstała, opierając się na słowie kobiet ${ }^{13}$. Jego wypowiedź wpisuje się w ówczesną mentalność, w której świadectwo kobiet nie miało większego znaczenia. A jednak stało się ono fundamentem orędzia chrześcijańskiego, na równi ze świadectwem uczniów, a nawet je poprzedzało!

Na uwagę zasługuje obecność w gronie niewiast Joanny, żony Chuzy (por. Łk 24,10), który był rządcą lub zarządzającym domem Heroda Antypasa, a więc owa kobieta należała do elit ówczesnego społeczeństwa ${ }^{14}$. Jej wędrowanie wraz z Jezusem i obecność przy grobie skoro świt świadczą o dużej niezależności kobiet. Ewangelista Jan, relacjonując przybycie Marii Magdaleny do grobu, stwierdza, że była pierwszą, która ujrzała pusty grób i powiadomiła Piotra i drugiego ucznia. Uczniowie przybyli, weszli do środka i wrócili do siebie. Maria Magdalena pozostała przy grobie i najpierw „ujrzała dwóch aniołów w bieli, siedzących tam, gdzie leżało ciało Jezusa - jednego w miejscu głowy, drugiego w miejscu nóg" (J 20,12). Obraz ten przypomina cherubów siedzących na Arce Przymierza (por. $1 \mathrm{Krl}$ 8,6-7), która znajdowała się w Miejscu Najświętszym w Świątyni Jerozolimskiej (por. $1 \mathrm{Krl} \mathrm{8,12-13).} \mathrm{Cheruby} \mathrm{strzegły} \mathrm{kapporetu}$ (gr. hilasterion), czyli przebłagalni (por. Kpł 16,14-16). Wierzono, że jest to miejsce, w którym uobecnia się moc Boża, dzięki której można dostąpić błogosławieństwa i darowania grzechów

13 Zob. Orygenes, Przeciw Celsusowi II,55.

14 Por. R. Brownrigg, Wszystkie postacie Nowego Testamentu, tłum. R. Stiller, Warszawa 2003, s. 118. 
(por. $2 \mathrm{Krl} 19,15)^{15}$. W Starym Testamencie arcykapłan tylko raz w roku, w Jom Kippur (Dzień Przebłagania), wchodził do Miejsca Najświętszego, by prosić o darowanie win własnych i ludu ${ }^{16}$. Teraz Miejscem Najświętszym jest grób, w którym Chrystus zmartwychwstał, a więc pokonał śmierć, która przyszła na świat przez grzech (por. Mdr 2,24). Maria nie weszła do grobu, zajrzała tylko do nowego „Miejsca Najświętszego”, w którym zobaczyła dwóch aniołów, jakby starotestamentowych cherubów adorujących obecność Boga pośród tego świata. Zaraz obróciła się i jak Szulamitka z Pieśni nad Pieśniami ${ }^{17}$ doświadczyła obecności Chrystusa Zmartwychwstałego (por. J 20,11-18) ${ }^{18}$. Maria znalazła się w tym momencie w nowej pozycji fizycznej i teologicznej, stanęła tyłem do grobu, naprzeciw Jezusa. Ta zmiana fizyczna to również zwrot teologiczny od rozpaczy do nadziei, którą ma zanieść braciom ${ }^{19}$. Prośba Jezusa skierowana do Marii: „Nie dotykaj Mnie”, może oznaczać, że w tym momencie, tu, na ziemi, objawia się boskość Jezusa, analogicznie jak objawiała się obecność Boga w Miejscu Najświętszym świątyni jerozolimskiej i nie można było zbliżać się do Arki Przymierza (por. 2 Sm 6,6). Następnie Jezus wezwał Marię po imieniu i powierzył jej nakaz

15 Por. J.R. Porter, Arka, w: Encyklopedia biblijna, red. P.J. Achtemeier, tłum. M. Wojciechowski, Warszawa 1999, s. 61-62; A. Mozgol, Teologia Arki Przymierza w Psalmach i w tradycji prorockiej (Ps 132; Jr 3,14-18; 2 Mch 2,1-8), Katowice 2003, s. 25-27.

16 Por. N. Kameraz-Kos, Święta i obyczaje żydowskie, Warszawa 1997, s. 48.

17 Już Hipolit Rzymski (170-235) uważał, że Szulamitka z Pieśni nad Pieśniami to prefiguracja Marii Magdaleny, a w postaci Umiłowanego powinno się rozpoznawać Chrystusa.

18 Szerzej o relacji literackiej między opisem Ewangelii Jana a Pieśnią nad Pieśniami pisze A. Nalewaj, zob. taż, Spotkanie Magdaleny i Zmartwychwstałego w Janowej Ewangelii (por. J 20,1-2.11-18) a poszukiwanie oblubieńca $w$ Pieśni nad Pieśniami w perspektywie intertekstulanej, w: Misja teologii w uniwersytecie, red. M. Jodkowski, A. Nalewaj, M Piechocka-Kłos, Olsztyn 2015, s. 203-215.

19 Por. J.L. Ska, Glina, taniec i ogród. Eseje z antropologii biblijnej, tłum. B. Rzepka, Kraków 2016, s. 108. 
misyjny: „udaj się do moich braci i powiedz im: «Wstępuję do Ojca mego i Ojca waszego oraz do Boga mego i Boga waszego»" (J 20,17).

Jako pierwszym ogłosiła dobrą nowinę uczniom: „Widziałam Pana i to mi powiedział" (J 20,18). Co się z nią stało po wniebowstąpieniu i zesłaniu Ducha Świętego? Według tradycji Kościoła wschodniego Maria Magdalena udała się do Rzymu, aby głosić Ewangelię, i tam spotkała się z cesarzem Tyberiuszem. Spotkanie odbyło się przy obiedzie. Maria Magdalena, trzymając w dłoni jajko, obwieściła cesarzowi: „Chrystus zmartwychwstał!”. Tyberiusz roześmiał się i odpowiedział, że człowiekowi równie łatwo powstać z martwych, jak trzymanemu przez Magdalenę jajku stać się czerwonym. W tym momencie jajko zmieniło kolor na czerwony. Stąd w Kościołach obrządku wschodniego wciąż żywa jest tradycja dzielenia się podczas Paschy czerwonymi jajkami, zaś w kulturach niektórych krajów wschodniej części Europy na Wielkanoc maluje się ozdobnie jajka. Według niektórych wschodnich tradycji Maria Magdalena pozostała w Rzymie do czasu przybycia św. Pawła. W Liście do Rzymian św. Paweł kazał pozdrowić Marię, „która poniosła wiele trudów dla waszego dobra" $(\mathrm{Rz} 16,6)$. Wschodnia tradycja uważa ową Marię za Marię Magdalenę. Na Wschodzie znana jest również tradycja, że Maria Magdalena przybyła wraz z Janem Apostołem do Efezu. Tam też umarła, a po śmierci została pochowana w grocie, w której w III wieku za panowania Decjusza pochowano żywcem siedmiu młodych chrześcijan - stąd nazwa groty Siedmiu Braci Śpiących ${ }^{20}$. W tradycji Kościoła doszło do połączenia kilku postaci biblijnych w jedną postać Marii Magdaleny. Proces utożsamiania dokonywał się na zasadzie analogii wykonanych czynów. W Ewangeliach pojawiają się dwie anonimowe kobiety, które przyszły namaścić Jezusa: jedna na początku Jego publicznej działalności (por. Łk 7,37-39), aby namaścić Jego stopy łzami

${ }^{20}$ Por. A. Welborn, Maria Magdalena, s. 111n. 
i olejkiem, druga u kresu Jego ziemskiej drogi, aby namaścić olejkiem Jego głowę (por. Mt 26,6-13; Mk 14,3-8). Jedno namaszczenie dokonało się $\mathrm{w}$ domu faryzeusza, drugie - $\mathrm{w}$ domu Szymona Trędowatego w Betanii. W pierwszym przypadku kobieta dostąpiła odpuszczenia grzechów, ponieważ „bardzo umiłowała" (por. Łk 7,47). Ewangelista, wspominając o tej kobiecie, mówi że: „prowadziła w mieście życie grzeszne” (Łk 7,37), co niekoniecznie musiało oznaczać, że była prostytutką, wszakże Jezus mówi o niej, że „[o]dpuszczone są jej liczne grzechy” (Łk 7,47), nie jeden, ale podtekst wydaje się sugerować, że przynajmniej jedną z form grzechu była rozwiązłość. O drugiej kobiecie ewangeliści mówią, że namaściła Pana „na dzień Jego pogrzebu" (Mk 14,8; Mt 26,12). A zatem dwie rzeczy - przebaczenie grzechów i wielka miłość - doprowadziły do utożsamienia tych dwóch kobiet z osobą Marii Magdaleny, a także do połączenia ich wszystkich z jeszcze inną Marią, siostrą Marty i Łazarza, przyjaciół Jezusa, u których mieszkał, gdy przebywał w Betanii. Ewangelista Jan wspomina o scenie, która się tam rozegrała: „Maria zaś wzięła funt szlachetnego, drogocennego nardowego olejku i namaściła Jezusowi stopy, a włosami swymi je otarła" (J 12,3).

Chociaż w tym przypadku namaszczono nogi, a nie głowę Jezusa, wszystkie namaszczające kobiety uważano za Marię z Betanii, siostrę Marty. Według ewangelisty Łukasza, Maria siedziała u stóp Pana, zamiast pomagać krzątającej się siostrze. Jezus bronił jej słowami: „Maria obrała najlepszą cząstkę, której nie będzie pozbawiona" (Łk 10,42).

W ten sposób nastąpiło połączenie grzesznicy, której odpuszczono wiele grzechów, z Marią, która wsłuchiwała się w naukę Jezusa. Słowo „namaszczenie”, odniesione do stóp i głowy Jezusa, sugerowało również namaszczenie Jego ciała przed złożeniem do grobu, dokonane przez pewne kobiety, wśród których wszyscy ewangeliści wymieniają Marię z Magdali (por. Mt 28,1; Mk 16,1; Łk 24,10; J 20,1). W ten sposób zrodziła się postać Ma- 
rii z Magdali, nawróconej grzesznicy, która stała się uczennicą Jezusa $^{21}$. Usankcjonował tę identyfikację papież Grzegorz I Wielki w homilii z 21 września 591 roku, w której skojarzył postać Marii Magdaleny z nawracającą się grzesznicą, zaprezentowaną w Ewangelii św. Łukasza (por. Łk 7,36-50) ${ }^{22}$. Chociaż skojarzenie wydaje się nietrafne, to jednak pokazuje, że w perspektywie rodzącego się Kościoła pojawia się propozycja otwarcia zbawienia dla wszystkich, nawet dla odrzuconych, pogardzanych i źle się prowadzących kobiet ${ }^{23}$. Papież Grzegorz Wielki, komentując przybycie Marii Magdaleny o świcie do grobu, podkreśla: „należy tu rozważyć, jaką miłością pałało serce tej niewiasty, iż nie odstąpiła od grobu Pana, gdy uczniowie odeszli. Szukała Tego, kogo nie znalazła. Szukała z płaczem, płonąc ogniem miłości. Gorzała pragnieniem zobaczenia Tego, o którym sądziła, iż Go wzięto. Toteż stało się, iż tylko ona Go wtedy zobaczyła, bo tylko ona została, aby Go szukać"24.

\section{Samarytanka - prowadząca dialog teologiczny z Jezusem}

W Ewangelii św. Jana pojawia się kolejna kobieta, która swoją wiarą wyprzedza postawę apostołów. Jest nią Samarytanka. W prezentacji jej osoby tytuł „kobieta” pojawia się aż trzynaście razy, jakby ewangelista chciał powiedzieć, że jest ona typem kobiety chrześcijanki, która niesie wiarę w środowisko zdomino-

${ }^{21}$ Por. B. Ward, Nierzadnice pustyni. Pokuta we wczesnych źródłach monastycznych, tłum. P. Długosz, Poznań 2005, s. 30n.

22 Św. Grzegorz Wielki, Homilie na Ewangelie, tłum. W. Szołdrski, Warszawa 1998, XXV, 1.

23 Por. A. Welborn, Maria Magdalena, s. 74n.

24 Zob. św. Grzegorz Wielki, Homilie na Ewangelie, tłum. W. Szołdrski, Warszawa 1969 (Pisma Starochrześcijańskich Pisarzy 3), s. 166-167. 
wane przez mężczyzn (por. J 4,1-42) ${ }^{25}$. Wyjątkowe znaczenie ma również jej pochodzenie ze wspólnoty Samarytan. Pochodzenie ząś tej społeczności pozostaje ciągle kwestią domysłów. Sugestia Józefa Flawiusza, że składała się ona w dużej mierze z ludności napływowej, jest wielce prawdopodobna. Asyryjczycy po zajęciu Samarii w 721 roku przed Chr. sprowadzili na to terytorium tysiące nowych osadników (por. 2 Krl 17,24nn). Okres niewoli babilońskiej również mógł sprzyjać osiedlaniu się nowych elementów etnicznych na terenie Izraela, ze względu na zniszczenie Jerozolimy, która nie mogła przeciwstawić się zajmowaniu przez obcych nowych przestrzeni. Natomiast po zajęciu w 322 roku przed Chr. Samarii przez Aleksandra Wielkiego osiedlono tu weteranów macedońskich ${ }^{26}$. Inną przyczyną wyodrębnienia się nowej wspólnoty mógł być konflikt rodzący się między powracającymi z niewoli a tymi, którzy w międzyczasie osiągnęli pewne przywileje społeczne i religijne. Niezadowoleni oddzielili się od Jerozolimy i podążali własną drogą religijną. Oczekiwania mesjańskie koncentrowali wokół postaci proroka, który będzie prawodawcą jak Mojżesz. Swoje nadzieje opierali na interpretacji tekstu Księgi Powtórzonego Prawa (Pwt 18,15-19) ${ }^{27}$. W późniejszych dokumentach Samarytan postać ta jest określana jako Taheb ${ }^{28}$. Zgodnie $\mathrm{z}$ tradycją prorok miał odnaleźć zgubione naczynia świątynne i ustanowić własną tradycję kultu Bożego nie w Jerozolimie, ale na Górze Garizim, na której, ich zdaniem, Jakub otrzymał wizję nieba opisaną

${ }^{25}$ Por. E. Adamiak, Kobiety w Biblii. Nowy Testament, Warszawa 2010, s. $145-148$.

26 Por. B. Górka, Jezus i Samarytanka (J 4,1-42). Historia i inicjacja, Kraków 2008, s. 19.

27 Por. L. Stachowiak, Ewangelia św. Jana, w: Pismo Święte Nowego Testamentu, t. 4, Poznań-Warszawa 1975, s. 181.

28 Por. G.R. Beasley-Murray, John, Dallas 1991 (Word Biblical Commentary 36), s. lxiv; J.R. Michaels, John, w: New International Biblical Commentary, Peabody 1998, s. 73; C.S. Keener, Komentarz historyczno-kulturowy do Nowego Testamentu, tłum. Z. Kościuk, Warszawa 2000, s. 195. 
w Księdze Rodzaju (Rdz 28,16-18) ${ }^{29}$. Tradycja Samarytan na tej górze umieszczała ołtarza wzniesiony przez Noego po potopie, ofiarę zastępczą za życie Izaaka oraz pierwszą ofiarę Izraelitów po wejściu do Ziemi Kanaan ${ }^{30}$. Tam też posiadali oni sanktuarium, gdzie składali Bogu ofiary. Sanktuarium to zostało w 128 roku przed Chr. zniszczone przez Jana Hirkana (134-104 rok przed Chr.), co pogłębiło już istniejącą nieufność Samarytan wobec Żydów. Mieszkańcy Galilei, podróżując do Jerozolimy, omijali kraj Samarytan, wybierając okrężną drogę za Jordanem, przez krainę zdominowaną przez Greków ${ }^{31}$. Ci, którzy odważyli się podróżować przez ziemię Samarytan, byli narażeni na różne niebezpieczeństwa. Znane jest wydarzenie z 52 roku po Chr., kiedy Samarytanie wybili grupę żydowskich pielgrzymów wędrujących przez Samarię do Jerozolimy ${ }^{32}$. Jeszcze większą nieufnością obdarzane były kobiety samarytańskie. Uważano, że od urodzenia mają one menstruację (por. Talmud Babiloński, Tohorot, Nidda 4,1), a więc są z natury nieczyste ${ }^{33}$. Zetknięcie się z taką kobietą powodowało zaciągnięcie nieczystości. Działo się to również poprzez korzystanie z naczyń, którymi posługiwali się Samarytanie ${ }^{34}$.

Samarytanka była nie tylko nieczysta, ale uważana za grzeszną, ponieważ miała już pięciu mężów, a obecnie żyła z mężczy-

29 Por. P. Perkins, Ewangelia wedtug świętego Jana, w: Katolicki komentarz biblijny, red. R.E. Brown, J.A. Fitzmyer, R.E. Murphy, Warszawa 2001, s. 1131.

30 Por. I. de la Potterie, Gesú Veritá. Studi di cristologia Giovanea, Torino 1973, s. 45.

${ }^{31}$ Por. B. Lindars, The Gospel of John, w: The New Century Bible Commentary, London 1982, s. 178.

32 Por. P. Johanson, Cywilizacja Ziemi Świętej, tłum. A. Nelicki, Kraków 1995, s. 136.

${ }^{33}$ Por. T. Okure, Ewangelia według św. Jana, w: Międzynarodowy komentarz do Pisma Świętego, ed. W.R. Farmer, tłum. A. Kuryś, Warszawa 2000, s. 1330.

34 Por. D. Daube, Jesus and the Samaritan Woman. The Meaning of 'sugcra, omai', „Journal of Biblical Literature” 69 (1950), s. 137-147. 
zną w nieformalnym związku. Ewangelista posługuje się tutaj amfibolią, czyli dwuznacznością sformułowania. Informuje, że Samarytanka posiadała pięciu mężczyzn, a szósty, z którym teraz przebywa, nie jest jej mężem (por. J 4,18) ${ }^{35}$. Z jednej strony informacja o pięciu mężczyznach ma znaczenie dosłowne świadczące, że Samarytanka prowadzi rozwiązły tryb życia. $Z$ drugiej strony ta informacja ma znaczenie symboliczne, spokrewnienia Samarytan z wieloma ludami. Autor Pierwszej Księgi Królewskiej wymienia pięć ludów, z których wywodzili się Samarytanie (por. $1 \mathrm{Krl} 17,24)^{36}$, a zatem czcili również bogów wyznawanych przez te ludy. W sensie teologicznym więc cudzołożyli. Samarytanka staje się personifikacją cudzołożnej Samarii i reprezentantką całego ludu (por. Oz 2,7). Jednak pod tym zewnętrznym obrazem kryje się jej bardziej skomplikowana sytuacja! Cóż to oznacza, że Samarytanka miała pięciu mężów? Stwierdzenie to sugeruje, że zawarła pięć legalnych, zgodnych z prawem małżeństw. Co się stało, że aż pięć razy musiała wychodzić za mąż? Czyżby pięć razy owdowiała? Mało prawdopodobne! A może pięć razy została wykorzystana przez mężczyzn, którzy dali jej list rozwodowy? Należy pamiętać, że w tamtych czasach kobieta miała ograniczone możliwości rozwiązania małżeństwa! ${ }^{37}$ Nawet

35 Szóstym mężczyzną mógł być żołnierz rzymski - kolonista, a koloniści zwyczajowo nie wchodzili w formalne związki z kobietami z Samarii. Por. J.K. Kim, Woman and Nation. An Intercontextual Reading of the Gospel John from a Postcolonial Feminist Perspective, Boston-Leiden 2004, s. 105.

36 Por. P.R. Gryziec, Spotkania przy studni. Rozważania o teologii Ewangelii wedtug św. Jana, Kraków 2000, s. 103n.

37 Teoretycznie w Izraelu kobieta mogła wystąpić z inicjatywą listu rozwodowego, ale bez zgody męża małżeństwo nie mogło być rozwiązane. Natomiast mąż mógł się rozwieść z żoną nawet z błahej przyczyny. Rabbi Hillel twierdził, że przyczyną wystarczającą jest źle ugotowany posiłek, a rabbi Akiwa sugerował, że mężczyzna może się rozwieść, jeżeli znajdzie kobietę ładniejszą od żony. Niestety nie jesteśmy pewni, czy rozwiązania prawne stosowane w Izraelu przyjmowano w Samarii, jednak możemy przypuszczać, że wspólne źródło, jakim była Tora, zbli- 
gdyby pięć razy owdowiała, to i tak miała problem, wszyscy mężczyźni bowiem ją omijali, bojąc się z nią związać. Zakładamy jednak, że bardziej prawdopodobne jest to, że przynajmniej jeden raz, a może więcej, została odrzucona przez mężczyznę poprzez list rozwodowy. Samarytanka tęskniła za normalnym życiem rodzinnym, poszukiwała więc mężczyzny, któremu można zaufać. Prawdopodobnie jednak nikt jej już nie chciał! Być może w swej desperacji związała się z legionistą, który nie mógł się z nią ożenić, bo zabraniało mu tego prawo. Była kobietą zdruzgotaną życiowo, poszukującą szczęścia, a ostatecznie odrzuconą i w odczuciu społecznym naznaczoną piętnem grzechu! Jezus czekał na Samarytankę przy studni, poprosił ją o wodę. W ówczesnej kulturze sytuacja przy studni jest dość dwuznaczna. Mężczyzna i kobieta sam na sam, bez świadków, a w dodatku to Żyd i Samarytanka. Dla ówczesnej mentalności zachowanie Jezusa było skandaliczne ${ }^{38}$. Gdy nadeszli uczniowie i zobaczyli ich razem, tylko przez szacunek wobec Mistrza nie wypowiedzieli swoich myśli: „ «Czego od niej chcesz?» lub: «Czemu z nią rozmawiasz?»" $(\mathrm{J} 4,27)$. Jezus rozumiał pragnienie Samarytanki ułożenia sobie życia (por. J 4,15), wiedział zarazem, jak skomplikowana jest jej sytuacja. Zaproponował jej ułożenie życia według nowych zasad, w mocy Ducha i w prawdzie, którą oferował w postaci Ewangelii (por. J 4,24). Samarytanka weszła w tę nową relację, którą stała się wiara w Tego, który da jej wodę życia. Oto niepowtarzalne oznaki spotkania. Oto konsekwencje spotkania. Spotkania, które nigdy nie jest obojętne. Spotkania, które nie pozostawia rzeczy w takim samym stanie, jak przed nim. Samarytanka porzuca dzban przy studni, to, co było do tej pory ważne i istotne, straciło na znaczeniu. Po tym spotkaniu ma już nowe perspektywy

żało systemy prawne. Por. P. Stasiuk, Małżeństwo Żydów, w: Małżeństwo $w$ Kościele katolickim oraz $w$ czterech religiach niechrześcijańskich (judaizm, islam, hinduizm, buddyzm), red. G. Dzierżon, Kraków 2014, s. 92-95.

38 Por. A. Pronzato, Kobiety, które spotkały Jezusa, tłum. K. Kozak, Kraków 2005, s. 16. 
w życiư ${ }^{39}$. Nie wiemy, jak dalej potoczyły się jej losy. Czy jej życie rodzinne w świetle ówczesnego prawa zostało uporządkowane? To pozostanie dla nas na zawsze tajemnicą. Z pewnością jednak poczuła się wartościową kobietą, to ją wybrał Jezus, by zaniosła wiarę swoim współrodakom, ją - w oczach ludzi grzeszną i odrzuconą!

Spotkanie Jezusa i Samarytanki przy studni przypomina spotkanie sługi Abrahama, szukającego małżonki dla Izaaka, i Rebeki (por. Rdz 24,10-27) oraz spotkanie Jakuba i Racheli (por. Rdz 29,1-12) ${ }^{40}$. Przy źródle dokonała się również interwencja Boża wobec „wygnanej” Hagar (por. Rdz 16,7) ${ }^{41}$. Odwołanie się do tła tych wydarzeń może sugerować wspólne korzenie wiary Samarytan i Żydów, które teraz tracą na znaczeniu w obliczu objawienia Jezusa. Niewykluczone, że autor mógł szukać odniesień do obrazu Mojżesza spotykającego przy studni Seforę (por. Wj 2,15). W opisie Józefa Flawiusza, dotyczącym tego spotkania, czytamy, że Mojżesz „dotarłszy do miejscowości Madian [...] usiadł obok studni i odpoczywał z powodu zmęczenia, a było około południa, w pobliżu miasta" 42 .

Prośba Jezusa: „Daj mi pić” (J 4,7), przypomina prośbę Eliasza, który spotykając wdowę w Sarepcie Sydońskiej, zawołał: „Daj mi, proszę, trochę wody w naczyniu, abym się napił” (1 Krl 17,10).

Prorok Eliasz, występujący w IX wieku przed Chr., był związany z Królestwem Północnym, którego centrum znajdowało się w Samarii, a jego pobyt w Fenicji stał się symbolem uniwersalnego posłania Bożego ${ }^{43}$. Zamieszkanie proroka u wdowy mogło

39 Por. tamże, s. 21.

${ }^{40}$ Por. B. Lindars, The Gospel of John, s. 180.

41 Por. G.L. Borchert, John 1-11, w: The New American Commentary, V. 25A, ed. E.R. Clendenen, Nashville 1996, s. 203.

${ }^{42}$ Zob. Józef Flawiusz, Dawne dzieje Izraela II, 11, 1; por. P.R. Gryziec, Spotkania przy studni, s. 91n.

${ }^{43}$ Wystąpienie proroka związane jest głównie z rządami króla izraelskiego Achaba (874-853 przed Chr.), który będąc wyznawcą jahwizmu, tolerował obce kulty, przede wszystkim fenickie. Por. A. Piwowar, Historia 
wzbudzać kontrowersje moralne, tak jak przebywanie Jezusa sam na sam z Samarytanką przy studni. A jednak Bóg wykorzystał to, co słabe w oczach świata: ubogą wdowę z Sarepty Sydońskiej i pogardzaną Samarytankę, by objawić swoją wolę. Wdowa z Sarepty Sydońskiej uwierzyła w Boga, w którego imieniu występował Eliasz (por. $1 \mathrm{Krl}$ 17,24). Również Samarytanka uwierzyła w Jezusa i zainicjowała tę wiarę u współbraci (por. J 4,39).

Woda ze studni Jakubowej może mieć również znaczenie symboliczne i może oznaczać Torę ${ }^{44}$. Esseńczycy opisywali Torę jako studnię wykopaną przez nauczycieli, z której czerpią swoje poznanie prawdy (CD 6,2-5) ${ }^{45}$. W Księdze Henocha woda to symbol mądrości, która wytryśnie w czasach ostatecznych (por. 1 Hen 48,1; 49,1 $)^{46}$. Samarytanie przyjmowali Torę i w szczególny sposób oczekiwali Mesjasza, proroka na wzór Mojżesza. Jezus przedstawiający się jako źródło wody żywej zastępuje Torę, z Niego możemy czerpać jako ze źródła łaski. Gdyby Samarytanie uznawali proroków, to również w symbolice wody żywej mogliby odczytać obecność Boga. Prorok Jeremiasz przedstawia słowa Boga: „Opuścili Mnie, źródło wody żywej” (Jr 2,13; por. Jr 17,13$)^{47}$.

Jezus wchodzący na terytorium Samarytan i spotykający się z kobietą przy studni przełamuje istniejące bariery. Wydarzenie to nabiera znaczenia symbolicznego otwarcia zbawienia dla wszystkich narodów.

Izraela czasów Starego Testamentu. Od patriarchów do podboju przez Rzymian, Lublin 2013, s. 135n.

${ }^{44} \mathrm{~W}$ pismach sapiencjalnych Starego Testamentu, a także w literaturze judaistycznej woda stanowi symbol Prawa. Por. I. de la Potterie. Maryja w tajemnicy przymierza, tłum. A. Tronina, Warszawa 2000, s. 209.

45 Zob. P. Muchowski, Rękopisy znad Morza Martwego Qumran - Wadi Murrbb $\square$ at - Masada, Kraków 1996, s. 197; Por. P. Perkins. Ewangelia wedtug świętego Jana, s. 1131.

46 Por. C.K. Barret, The Gospel According to St John an Introduction with Commentary and Notes on the Greek Text, London 1972, s. 195.

47 Por. P.R. Gryziec, Spotkania przy studni, s. 94. 
Spotkanie Jezusa i Samarytanki odbyło się około szóstej godziny (por. J 4,6b), czyli w samo południe, a więc w czas największego skwaru. Nie był to odpowiedni moment, aby iść do studni i czerpać wodę. Być może Samarytanka pragnęła uniknąć spotkania ze swoimi koleżankami z powodu niepowodzeń w życiu osobistym, bała się drwin, a więc wybrała tę nietypową porę. Jednak czas spotkania ma przede wszystkim znaczenie teologiczne. Przypomina rozpoczęcie procesu zbawczego, którego znakiem starotestamentowym był czas zwiastowania Abrahamowi przyjścia na świat jego syna Izaaka.

„Pan ukazał się Abrahamowi pod dębami Mamre, gdy ten siedział u wejścia do namiotu w najgorętszej porze dnia. Abraham, spojrzawszy, dostrzegł trzech ludzi naprzeciw siebie" [...] Rzekł mu [jeden z nich]: «O tej porze za rok znów wrócę do ciebie, twoja zaś żona Sara będzie miała wtedy syna»" (Rdz 18,1.10).

Sara nie była jeszcze gotowa na zwiastowaną prawdę i miała wątpliwości wiary. Natomiast Samarytanka była gotowa przyjąć, że na świecie narodził się Zbawiciel. Czas spotkania w samo południe nabiera nowego znaczenia, zapowiadając chwilę skazania Jezusa na śmierć: „Był to dzień Przygotowania Paschy, około godziny szóstej” (J 19,14). Właśnie wtedy Piłat wyprowadził Jezusa i „zasiadł na trybunale, na miejscu zwanym Lithostrotos" $(\mathrm{J} 19,13)^{48}$. Jezus siedzący na kamieniu studni zapowiada wydarzenie krzyża, z którego popłynie woda żywa, czyli Jego sakramentalna obecność we wspólnocie. Jeszcze dwukrotnie będzie potwierdzał nadejście tej godziny (por. J 4,21.23), w której rozpocznie się składanie nowej ofiary, zacznie funkcjonować kult „w Duchu i prawdzie” (J 4,23). Stwierdzenie, że ta godzina „już jest” (J 4,23), sugeruje antycypację wydarzenia krzyża już w samym fakcie przyjścia Mesjasza. Dlatego dla Samarytanki ta godzina nadeszła z chwilą przyjęcia wiary w Jezusa jako Mesjasza i Zbawiciela świata ${ }^{49}$. Czuje się wezwana przez Niego, aby

\footnotetext{
48 Tamże, s. 95n.

49 Tamże, s. 107n.
} 
być uczennicą, i tak jak uczniowie odpowiedzieli Mu, porzucając łodzie i sieci, aby pójść za Nim (por. Mk 1,16-20; Mt 4,18-22), tak samo pozostawia dzban przy studni i udaje się do miasta, już jako uczennica i misjonarka, apostołka ${ }^{50}$. Od swoich współrodaków usłyszy słowa trochę ją lekceważące: „Wierzymy już nie dzięki twemu opowiadaniu, usłyszeliśmy bowiem na własne uszy i wiemy, że On prawdziwie jest Zbawicielem świata" (J 4,42). Nie odpowiada, nie polemizuje, usuwa się po prostu w cień, bo wypełniła swoją inspirującą rolę doprowadzenia rodaków do wiary!

\section{Marta i Maria - modele uczennic Jezusa}

Ewangelista Łukasz kontrastuje zachowanie Marty i Marii wobec Jezusa, ale mogą to być w ogóle odmienne postawy życiowe (por. Łk 10,38-42). Gościnność Marty i Marii przybiera dwie postawy. Marta obiera drogę dawania, czynienia i wykonywania pracy dla gościa, który przybywa do ich domu. Maria zaś przyjmuje postawę bierną przyjmowania, pozwolenia, by gość kształtował jej życie. W ich postawach można uchwycić dwie możliwe kobiece role:

- tę tradycyjną - gospodyni domowej i pani gospodarstwa;

- tę nową, prawie rewolucyjną - kobiety, która odchodzi od garnków i zapoczątkowuje postawę uczennicy ${ }^{51}$.

Maria „siadła u nóg Pana i przysłuchiwała się Jego mowie”, co oznacza, że weszła w relację z Jezusem jako nauczycielem, przyjmując postawę uczennicy, zasłuchania, u Jego stóp (pros tous podas; zob. Łk 10,39), podobnie Paweł opisuje siebie samego jako ucznia, który u stóp (pros tous podas; zob. Dz 22,3) Gamaliela otrzymuje staranne wykształcenie.

Marta próbuje zaimponować Jezusowi swoją postawą dobrej gospodyni i trochę z zazdrością zauważa, że siostra wpatrzona

50 Por. E. Bianchi, Jezus i kobiety, tłum. M. Rychert, Poznań 2018, s. 99.

51 Por. A. Pronzato. Kobiety, które spotkaty Jezusa, s. 101. 
w Jezusa słucha Jego słów. $Z$ wyrzutem zwraca uwagę, próbując odciągnąc siostrę od Niego: „Panie, czy Ci to obojętne, że moja siostra zostawiła mnie samą przy usługiwaniu? Powiedz jej, żeby mi pomogła" (Łk 10,40). Marta przesadnie wciąga Jezusa w relację zazdrości i rywalizacji między siostrami. Jest kobietą zbytnio zapatrzoną w siebie, co ukazuje jej wypowiedź: „moja siostra zostawiła mnie samą przy usługiwaniu. Powiedz jej, żeby mi pomogła". Możemy stwierdzić, że jej horyzont jest ograniczony, jej osobowość została zdławiona w rywalizacji z siostrą, ale przede wszystkim jest ofiarą dominującej kultury, która przypisywała kobietom rolę z góry określoną, ograniczoną do usługiwania w rodzinie, ojcom i mężom ${ }^{52}$. Sytuacja pozornie zmienia się w obliczu śmierci brata, Łazarza. Marta, pozostawia dom i wychodzi na spotkanie Jezusa z sercem pełnym wyrzutów: „Panie, gdybyś tu był, mój brat by nie umarł” (J 11,21). Podejmuje dyskusję teologiczną z Jezusem na temat zmartwychwstania. W końcu pełna determinacji wyznaje wiarę: „Tak, Panie! Ja wciąż wierzę, że Ty jesteś Mesjasz, syn Boży, który miał przyjść na świat" (J 11,27). Wygląda na to, że Maria, która pozostała w domu, nic nie wie o przybywającym Jezusie (por. J 11,20). Ewangelista sugeruje, że Jezus rozmawiając z Martą, zapytał, co z Marią, jak ona przeżyła śmierć brata. Marta czuje się zobowiązana poinformować Marię, że przybył Jezus i woła ją. Maria identycznie jak jej siostra zwraca się z wyrzutem do Jezusa: „Panie, gdybyś tu był, mój brat by nie umarł” (J 11,32). Jezus, widząc jej łzy, wzrusza się i przystępuje do działania - każe usunąć kamień z grobu. Marta protestuje: „Panie, już cuchnie. Leży bowiem od czterech dni w grobie" (J 11,39). Z opisu Janowego wyłania się postać Marty, która ciągle aktywna opuszcza dom, by wyjść na spotkanie z Jezusem i wyżalić się Mu z powodu utraty brata. Maria przyjmuje postawę wyczekującą w domu, śmierć brata przeżywa w samotności, dopiero na prośbę Jezusa opusz-

${ }_{52}$ Por. E. Bianchi, Jezus i kobiety, s. 58. 
cza dom. Obraz charakterów dwóch sióstr zaprezentowany przez ewangelistów Łukasza i Jana pokrywa się, Marta jest aktywna, gotowa do działania, Maria przyjmuje postawę wyczekującą, pasywną, przeżywa śmierć brata w zaciszu domowym. Ciekawe, że Marta, wychodząc z domu na spotkanie Jezusa, nie zabrała z sobą siostry, a dopiero później informuje ją, że Nauczyciel przybył i chce ją widzieć. Czyżby rywalizacja między siostrami, która jest lepsza? Jezus pragnie przezwyciężyć rywalizację sióstr o czas spędzony w Jego obecności, pragnie, by obydwie siostry wzajemnie się miłowały, a wówczas otworzą się na Jego orędzie. Jezus mówi, potrzeba tylko jednego! Czego? Wzajemnej miłości, bo dopiero wówczas otwieramy nasze serca na Jego słowo. O tej miłości mówią siostry, gdy informują Jezusa: „Panie, oto choruje ten, którego kochasz (gr. phileis)” (J 11,3). Ewangelista dodaje, że „Jezus miłował (gr. ègapa) Martę i jej siostrę, i Łazarza” (J 11,5). Język grecki pozwolił ewangeliście zaprezentować różne odcienie miłości, w których wyraża się to uczucie wobec Łazarza (gr. phileo) i wobec całej wspólnoty (gr. agapao). Relacja z Łazarzem opiera się na przyjaźni, która była przez wielu Greków uważana za najgłębszą relację międzyludzką, a miłość we wspólnocie oparta jest na postawie wzajemnego wspierania się i obdarzania dobrem. Jezus nie wstydzi się swej miłości do Łazarza! Okazuje swoje cierpienie z powodu utraty przyjaciela płaczem (por. J 11,35), a zgromadzeni Żydzi wypowiedzieli znamienne słowa: „Oto jak go miłował” (gr. phileo). Zaskakujący jest jeszcze jeden fakt, że w tym domu mieszka tylko rodzeństwo. Nie słyszymy nic o rodzicach, nie wspomina się o mężach sióstr! Czyżbyśmy mieli do czynienia ze wspólnotą esseńczyków, gdzie zawieranie małżeństwa nie traktowano jako konieczności, a nawet preferowano życie w samotności, bo to dawało większą możliwość zgłębiania tekstów świętych ${ }^{53}$. W tym kontekście utrata brata stawia ich w trudnej sytuacji egzystencjalnej, ponieważ

53 Zob. Józef Flawiusz, Wojna żydowska 2.120. II, 11, 1. 
zostają dwie siostry bez mężczyzny w domu, co w tamtej epoce zagrażało ich bytowi materialnemu. Jezus, wskrzeszając Łazarza, przywraca jego siostrom stabilizację w relacjach ówczesnego porządku społecznego.

Jezus, wchodząc w bliskie relacje z Marią i Martą, przełamuje ówczesne zasady kulturowe powiązane z normami religijnymi. Przebywanie u kobiet i ich nauczanie łamało dobre obyczaje, na straży których stali ówcześni uczeni w Piśmie. Tymczasem co widzimy? Marta przyjmuje Jezusa do domu, a jej siostra siada u Jego stóp i słucha Jego nauki. Jezus chętnie z nimi przebywa, chętnie naucza. Wydaje się, że na sześć dni przed Paschą, gdy ponownie przybył do Betanii i zastał w domu troje rodzeństwa, $\mathrm{w}$ ich domu zapanowała radość $\mathrm{z}$ bycia razem ${ }^{54}$.

\section{Kobiety w służbie ewangelizacji}

W życiu pierwotnego Kościoła kobiety miały duże znaczenie w posłudze ewangelizacyjnej. Wraz z zamknięciem przymierza opartego na znaku obrzezania, które preferowało mężczyzn, rozpoczął się czas równości wobec Boga przy wejściu do wspólnoty. Chrzest był jednakowy dla mężczyzn i kobiet, jego skutki również były identyczne. W pierwotnym Kościele przeciwko temu egalitaryzmowi zrodziła się opozycja, która nauczała: „Jeżeli się nie poddacie obrzezaniu według zwyczaju Mojżeszowego, nie możecie być zbawieni" (Dz 15,1; por. Dz 15,5).

Spotkanie apostolskie, które odbyło się w 49 roku po Chr., zerwało z przepisami rytualnej czystości i otworzyło przestrzeń zbawienia dla wszystkich wyznających wiarę w Jezusa. Wobec tego Paweł wyjaśniał wspólnocie w Galacji: „wszyscy, którzy zostaliście ochrzczeni w Chrystusie, przyoblekliście się

54 Por. K. Wons, Przyjaciele Jezusa, Maria, Marta i Łazarz, Kraków 2019, s. 28. 
w Chrystusa. Nie ma już Żyda ani poganina, nie ma już niewolnika ani człowieka wolnego, nie ma już mężczyzny ani kobiety, wszyscy bowiem jesteście kimś jednym w Chrystusie Jezusie" (Ga 3,27-28) ${ }^{55}$. To radykalny zwrot spojrzenia na człowieka, ale przede wszystkim na pozycję kobiety, którą przepisy rytualnej czystości stawiały wielokrotnie poza życiem społecznym, w szczególności w czasie okresu krwawienia, gdy zetknięcie się z nią było zaciągnięciem nieczystości.

Piotr po uwolnieniu udał się „do domu Marii, matki Jana, zwanego Markiem, gdzie zebrało się wielu na modlitwie" ( $\mathrm{Dz} 12,12)$. Najwyraźniej dom Maryi był centrum ewangelizacyjnym, domowym kościołem, skoro tam gromadzono się na modlitwie. Dobrą nowinę o uwolnieniu Piotra zaniosła wspólnocie dziewczyna o imieniu Rode (por. Dz 12,14), co nabiera symbolicznego znaczenia niesienia przez kobiety orędzia o zbawieniu często jeszcze przed mężczyznami ${ }^{56}$.

Jak wielkie znaczenie miały kobiety w pierwotnym Kościele, określa św. Paweł, pozdrawiając wspólnotę w Rzymie, w której wiele kobiet wymienia z imienia, poczynając od diakonisy Febe, która posługiwała we wspólnocie w Kenchrach (por. Rz 16,1) poprzez trudzących się dla ewangelizacji Tryfenę, Tryfozę i Persydę (por. $\mathrm{Rz} \mathrm{16,12)} \mathrm{oraz} \mathrm{Julię} \mathrm{i} \mathrm{nieprzedstawianą} \mathrm{z} \mathrm{imienia} \mathrm{matkę}$ Rufusa czy siostrę Nereusza (por. Rz 16,13-14) ${ }^{57}$. W głoszenie Ewangelii były zaangażowane także Ewodia i Syntacha, między którymi prawdopodobnie dochodziło do jakichś sporów, skoro Paweł wzywa je do jednomyślności w Panu (por. Flp 4,2). Wydaje się, że wypełniająca posługę diakonisy Febe była doręczycielem listu do wspólnoty w Rzymie, a zatem musiała być dobrze

55 Por. E. Achtemeier, Kobiety, w: Słownik wiedzy biblijnej, red. B.M. Metzger, M.D. Coogan, tłum. P. Puchciarek, Warszawa 1996, s. 300.

56 Por. D. Marzotto, Piotr i Magdalena. Ewangelia na dwa głosy, tłum. Z. Kasprzyk, Kraków 2016, s. 83-88.

$57 \mathrm{Na}$ temat posługi diakonis w pierwotnym Kościele szerzej pisze J. Załęski, Obraz kobiety w listach Nowego Testamentu, Ząbki 2005, s. 137-179. 
poinformowana o jego treści, tak aby mogła ustnie uzupełnić informacje w nim zawarte oraz odpowiedzieć na pytania adresatów, które mogły być związane z jego treścią. Ponieważ List do Rzymian porusza fundamentalne prawdy wiary, należałby uznać Febe za przygotowaną do posługi prowadzenia refleksji teologicznej, dyskursu naukowego na temat kształtujących się prawd wiary w chrześcijaństwie ${ }^{58}$. Jakże wielkie zaufanie posiadał Paweł do wiedzy teologicznej tej kobiety, skoro jej powierzył misję dostarczenia listu wspólnocie, która z pewnością już posiadała zręby ukształtowanej wiary w Chrystusa. Jakże wielkie było to wyzwanie przed Febe, która jako kobieta miała przekonywać do teologii reprezentowanej przez Pawła! Należy również zauważyć, że diakonisa posługiwała w jednej z ważniejszych wspólnot pierwotnego chrześcijaństwa. Kenchry były jednym z dwóch portów Koryntu, leżącym po jego wschodniej stronie i otwierającym się w stronę Zatoki Aegina, a przez nią dalej ku Morzu Egejskiemu. Pod koniec I wieku po Chr. autor Listu do Tymoteusza, stawiając kryteria wymagane do przyjęcia posługi diakona, wymienia analogiczne kryteria wobec kobiet: „godne, nieskłonne do oczerniania, trzeźwe, wierne we wszystkim" (1 Tm 3,11). A więc diakonisa Febe z dużym prawdopodobieństwem pełniła analogiczną posługę, jaką wykonywali diakoni.

Wśród adresatów Listu do Filemona pojawia się Apfia, którą Paweł najwyraźniej traktuje jako współodpowiedzialną za wspólnotę Kościoła gromadzącą się w domu Filemona. W pierwotnym Kościele pojawiają się „siostry”, które wspierają ewangelizację. Zresztą w czasie konfliktu ze wspólnotą w Koryncie Paweł usłyszał zarzut o obecność przy nim kobiety. Wówczas, broniąc się, zadaje pytanie: „Czyż nie wolno nam brać z sobą niewiasty-siostry, podobnie jak to czynią pozostali apostołowie oraz bracia Pańscy i Kefas?" (1 Kor 9,5). Jak widać, obecność kobiet w procesie ewangelizacji w pierwotnym Kościele była niemalże

58 Por. P. Nyk, Diakońskie postugiwanie kobiet w świadectwie Nowego Testamentu, „Verbum Vitae” 19 (2011), s. 188. 
powszechna. W jakimś stopniu mogła to być forma kontynuacji wspólnoty niewiast podążających za Jezusem i Jego uczniami.

Od samego początku w Kościele szczególnym uznaniem cieszyły się wdowy, poczynając od proklamującej czas zbawienia prorokini Anny ze świątyni jerozolimskiej, a kończąc na instytucji kobiet wypełniających posługę modlitewną (por. $1 \mathrm{Tm}$ 5,3-16). Zachęta autora Listu do Tymoteusza, by młodsze wdowy wychodziły za mąż, sugeruje, że podłożem powstania instytucji wdów w pierwotnym Kościele były kwestie materialne. Dzięki małżeństwu wdowy otrzymywały środki potrzebne do życia. Należy pamiętać, że w ówczesnym społeczeństwie to głównie na mężczyznach spoczywał obowiązek utrzymania rodziny. Natomiast starszym wdowom, którym trudno byłoby znaleźć męża, wspólnota powinna starać się zapewnić byt (por. $1 \mathrm{Tm} 5,16$ ).

Pierwotny Kościół pokonał również głęboko zakorzenione w judaizmie poglądy o deprecjacji wartości kobiety, która nie ma dzieci. Rachela (por. Rdz 29,30-31; 35,16-20) i Anna (por. 1 Sm 1) cierpiały z powodu swej bezpłodności. Święty Paweł wyjaśniał wspólnocie w Koryncie, jak wielkie znaczenie przed obliczem Bożym miało dziewictwo (por. 1 Kor 7,25-40). W ten sposób pokonał również pogląd zakorzeniony w kulturze hellenistycznej, jakoby dziewictwo cenione było w sferze boskiej, bogini Ateny, ale nie miało wartości w konkretnym życiu. Wprawdzie Rzymianie cenili dziewice - westalki, ale była to bardzo wyjątkowa posługa. W codzienności zaś liczyła się kobieta wypełniająca obowiązki małżeńskie. Niestety w dalszym etapie rozwoju Kościoła pojawiły się postawy, które negowały, a nawet potępiały małżeństwo. Enkratyści podkreślali wyższość dziewictwa nad małżeństwem; uznawali celowe bezżeństwo za jedynie słuszny wybór życia przez chrześcijan, a aktywność płciową uważali za grzeszną ${ }^{59}$. Małżeństwo uważano za "gorzką roślinę”, któ-

59 Por. D. Muszytowska, Żona zbawiająca męża (1 Kor 7,16)?, „Verbum Vitae" 19 (2011), s. 150n. 
rej owocu Pan w raju zakazał spożywać ${ }^{60}$. Zwolennicy tej drogi wzywali do rozejścia się małżonków i życia w celibacie. Uważali, że rodzenie i śmierć, które są powiązane, zakończyły się wraz z przyjściem Chrystusa oraz że od tej pory nie ma już mężczyzny ani kobiety, że płciowość nie istnieje ${ }^{61}$. Enkratyzm dominował w chrześcijaństwie Wschodu. Jego echo pobrzmiewa w Ewangelii Egipcjan, Ewangelii Tomasza, Ewangelii Filipa, Dziejach Piotra, Dziejach Filipa, Dziejach Tomasza. Szerokie spektrum utworów apokryficznych przesiąkniętych ideą enkratyzmu świadczy o jego popularności w rodzącym się chrześcijaństwie.

Pierwotny Kościół, zmagając się z ewangelizacją w warunkach oskarżeń o burzenie porządku społecznego w Imperium Rzymskim, starał się udowodnić, że podtrzymuje starożytne zwyczaje i stąd zachęta św. Piotra, żeby „żony były poddane mężom" (1 P 3,1), co potwierdzała również wspólnota św. Pawła (por. Ef 5,22). Pamiętajmy, że ideał kobiety w starożytnej Grecji kreował ją na cichą piastunkę domowego ogniska. Eurypides w Heraklidach wkłada w usta Makarii słowa wyjaśniające jej pojawienie się na scenie:

Nie myślcie, obcy, że wychodzę do was z zuchwalstwa - o to was po pierwsze proszę.

Kobieta milczeć ma, znać swoje miejsce, w domu spokojnie siedzieć - tak najpięknieje ${ }^{62}$.

Ukazując się tłumowi Ateńczyków, Makaria stawia pod znakiem zapytania swój status przyzwoitej panny szlachetnego pochodzenia, dlatego czuje się zmuszona odnieść do tej sytuacji ${ }^{63}$.

60 Por. Klemens Aleksandryjski, Strom (Kobierce) III, 9, 66, tłum. J. Niemirska-Pliszczyńska, Warszawa 1994.

61 Por. J. Danielou, Teologia judeochrześcijańska, tłum. S. Basista, Kraków 2002, s. 107.

${ }^{62}$ Eurypides, Heraklidy, w. 474-477.

${ }_{63}$ Por. K. Pietruczak, Kobieta $w$ przestrzeni scenicznej, kobieta w przestrzeni publicznej. O tragicznej konwencji jako elemencie kreowania ideatu i anty- 
Jakże sformułowanie Eurypidesa przypomina nakaz Pawła skierowany do wspólnoty w Koryncie: „kobiety mają na tych zgromadzeniach milczeć; nie dozwala się im bowiem mówić, lecz mają być poddane, jak to Prawo nakazuje" (1 Kor 14,34). Prawdopodobnie Paweł tym sformułowaniem odpierał zarzuty kierowane pod adresem jego wspólnoty, że zbytnio pozwala przewodzić kobietom, a więc burzy przyjęty porządek społeczny. Jednak już sama konieczność wypowiedzenia tych słów świadczy o tym, że $\mathrm{w}$ pierwotnym Kościele w wielu wspólnotach kobiety zabierały głos i uczestniczyły w oficjalnym nauczaniu.

We wspólnocie korynckiej Paweł musiał zająć stanowisko w sprawie nakrycia głowy u kobiet w czasie zgromadzenia liturgicznego (por. 1 Kor 11,2-16). W kulturze Mezopotamii zwyczaj nakrywania głów przez kobiety zamężne symbolizował związek małżeński, tak jak współcześnie obrączki. W Koryncie, w mieście portowym, ścierały się różne zwyczaje i stąd dyskusja we wspólnocie. Paweł był zwolennikiem uszanowania tradycji, co nie oznacza, że w ten sposób deprecjonował status kobiet ${ }^{64}$. Należy zatem stwierdzić, że wpływ mentalności greckiej i prawa rzymskiego ograniczył prerogatywy kobiet w Kościele, co jeszcze bardziej widać w kolejnej epoce. Polikarp, biskup Smyrny, pisząc List do Filipian około 110 roku po Chr., starał się ograniczyć działalność kobiet, wyraźnie określając ich rolę jako dziewic, wdów i zawsze wiernych żon. Tertulian widział ideał kobiety w całkowicie uległym życiu, w najdrobniejszych szczegółach uregulowanym przez ścisłe normy ${ }^{65}$.

ideału kobiety $w$ Atenach $V$ w. p.n.e., w: Ideat $i$ antyideł kobiety $w$ literaturze greckiej i rzymskiej, red. A. Marchewka, Gdańsk 2018, s. 47.

${ }^{64}$ Szerzej na temat interpretacji 1 Kor 11,2-16 pisze J. Załęski, Obraz kobiety w listach Nowego Testamentu, s. 21-87.

65 Por. V. Abrahamsen, Kobiety, w: Stownik wiedzy biblijnej, s. 311; J. Rączka, Czy legendę Tekli ocenzurowano? Świadectwo Tertuliana o apokryficznych Dziejach Pawła (De baptismo 17,5), „U Schyłku Starożytności. Studia Źródłoznawcze" 10 (2011), s. 111-130. 
Od II wieku po Chr. wielkim cieniem na pozycji kobiety położyła się rozwijająca się gnoza ${ }^{66}$, która odrzucając cielesność i seksualność, doprowadziła do pogardy życia małżeńskiego ${ }^{67}$. Rezygnacja $z$ małżeństwa i określonych pokarmów (przede wszystkim zwierzęcych) należała do pierwszych nakazów gnostyckiej ascezy. Kobieta uchodziła w wielu ugrupowaniach za „dzieło szatana”. Stąd, powiadają marcjonistyczni sewerianie (III wiek), „ci, którzy się łączą węzłem małżeńskim, spełniają dzieło szatana". Człowiek bowiem od pępka w górę jest tworem "siły Boga”, od pępka w dół natomiast tworem złej siły: wszystko, co dotyczy rozkoszy, namiętności i żądzy, dzieje się od pępka w dół ${ }^{68}$. Gnostycka Ewangelia Filipa rozdzielenie płci przedstawia jako czyn zawiniony przez kobietę (Ewę) i łączy je z nastaniem śmiertelności. Jedność jest życiem, rozdzielenie śmiercią - oto przewodnia teza gnostyckiego myślenia. „Gdy Ewa była w Adamie, nie było śmierci. Gdy odłączyła się od niego, nastała śmierć. Jeśli ponownie wyjdzie i weźmie ją (śmierć) do siebie, nie będzie śmierci. [...] Gdyby kobieta nie oddzieliła się od mężczyzny, nie umarłaby z mężczyzną. Jej oddzielenie stało się początkiem śmierci i dlatego przyszedł Chrystus, aby oddzielnie, które było na początku, ponownie oddalić, a ich

66 Nazwa „gnostycyzm”, która stała się wspólnym nagłówkiem dla doktryn głoszonych przez rozmaite sekty, które pojawiły się w obrębie chrześcijaństwa i wokół niego w ciągu pierwszych przełomowych wieków jego istnienia, wywodzi się z greckiego słowa gnosis, oznaczającego „wiedzę”. Nacisk położony na wiedzę jako środek osiągnięcia zbawienia, a także przypisywanie sobie takiej wiedzy w formie własnej określonej doktryny to cechy wspólne rozlicznych sekt, w których wyrażał się historycznie ruch gnostycki. Por. H. Jonas, Religia gnozy, tłum. M. Klimowicz, Kryspinów 1994, s. 48.

67 Jedną z charakterystycznych cech gnozy jest dualizm ducha i materii, przy czym materia jest więzieniem dla rzeczywistości duchowej. Por. G. Quispel, Gnoza, tłum. B. Kita, Warszawa 1988, s. 33nn.

${ }^{68}$ Por. K. Rudolph, Gnoza, tłum. G. Sowinski, Kraków 2003, s. 246. 
dwoje połączyć - zmarłych w oddzieleniu obdarzyć życiem i połączyć" ' $^{\circ}$.

Niektórzy gnostycy poszli w kierunku wspólnoty cielesnej, zakładając wspólnotę dóbr, w którą wpisywano również kobiety. W ten sposób nastąpiło oddzielenie miłości od seksualności, jakby te dwie rzeczywistości wzajemnie się nie warunkowały ${ }^{70}$. Karpokrates i Epifanes, przedstawiciele tego kierunku gnozy, najwyraźniej zastosowali nadinterpretację myśli Platona, który w Państwie żąda, by kobiety stały się wspólnym dobrem wszystkich ${ }^{71}$.

Dominujący nurt gnozy uważał prokreację za rzeczywistość negatywną, w konsekwencji zawieranie małżeństwa za rzecz zbyteczną ${ }^{72}$. Stąd w gnozie pojawiły się kobiety, które pragnęły się wyzwolić z okowów związku małżeńskiego bez miłości. Małżeństwo w środowisku greckim wielokrotnie służyło mężczyznom tylko do prokreacji, a w tle pozostawały konkubiny, które wypełniały przestrzeń życia erotycznego. Zatem dla wielu kobiet pragnących się wyzwolić z tego dualizmu swojej roli w świecie greckim, gnoza jawiła się jako przestrzeń wolności, wprawdzie bez doświadczenia miłości od mężczyzny, ale z prestiżem we wspólnocie w zamian.

Bezpośrednią przyczyną skazania św. Piotra na śmierć, według zabarwionych poglądami gnostyckimi Dziejów Piotra, było wejście na drogę czystości nawróconych Rzymianek. Autor w ten sposób relacjonuje zaistniałą sytuację:

„Przyszły do Piotra razem konkubiny prefekta Agryppy; było ich cztery: Agryppina, Nikaria, Eufemia i Doris. Wysłuchawszy nauk na temat czystości oraz wszystkich słów Pana, przejęły się do głębi serca, i postanowiły między sobą, że zachowają czystość i zaprzestaną dzielić łoże z Agryppą. [...] Także pewna kobieta,

${ }^{69}$ Por. tamże, s. 270.

70 Por. Klemens Aleksandryjski, Kobierce III 5,1-30.

${ }^{71}$ Por. Platon, Państwo V 457 D.; Klemens Aleksandryjski, Kobierce III 5, $1-11$.

${ }^{72}$ Por. Klemens Aleksandryjski, Kobierce III 12,1-3. 
niezwykłej urody, imieniem Ksantyppa, żona Albinusa, przyjaciela Cezara, przyszła również do Piotra wraz z innymi zamężnymi kobietami, i ona również odsunęła się od Albinusa. [...] Albinus przedstawił swoją sytuację Agryppie, mówiąc: Albo ty zemścisz się na Piotrze, który odsunął moją żonę ode mnie, albo ja zemszczę się sam. I Agryppa odparł mu, że jest w takiej samej sytuacji: Piotr oddalił moje konkubiny ode mnie. A Albinus odrzekł mu: Agryppo, na co więc czekasz? Schwytajmy go i wydajmy go na śmierć jako czarownika, abyśmy mogli odzyskać nasze żony i pomścić innych mężów, którzy go nie mogą zabić, lecz od których również odciągnął żony"73.

Czy zatem w gnozie kobiety nie posiadały znaczenia? Czasami miały znaczącą pozycję, ale był to nowy typ kobiety, wolnej od życia rodzinnego, aseksualnej, gotowej do wejścia na drogę poznania (gnozy). Często dostępowały one kierowniczych stanowisk - jako nauczycielki, prorokinie i misjonarki czy celebrantki ceremonii kultowych i działań magicznych (egzorcyzmy) ${ }^{74}$. Pozornie mogłoby się wydawać, że był to znaczący awans dla niektórych kobiet, jednak cena była jeszcze większa - rezygnacja z życia rodzinnego i całkowite podporządkowanie celom wspólnoty, w której ich cielesność dostępowała pogardy.

Jakże trudno w tych warunkach było wspólnocie Kościoła budować właściwy obraz kobiety, z jednej strony nie gubiąc jej powołania do bycia małżonką i posiadania dzieci, z drugiej zachęcając do właściwego zaangażowania w proces ewangelizacji. Pierwotna wspólnota Kościoła rozpoczęła budować pozycję kobiety na podwójnej relacji miłości, do Boga i do małżonka. W lustrzanym odbiciu mężczyzna powinien kształtować swoje życie w relacji miłości do Boga i małżonki.

Mimo olbrzymich ograniczeń kulturowych, kobiety odegrały znaczącą rolę w kształtowaniu się pierwotnej wspólnoty Kościo-

${ }_{73}$ Zob. Dzieje Piotra - męczeństwo, tłum. M. Starowieyski, Kraków 2007, s. 33-34.

74 Por. K. Rudolph, Gnoza, s. 210. 
ła. Na drogach ewangelizacji św. Pawła pojawili się: wspaniałe małżeństwo, Pryscylla i Akwila, które go wspomagało w Koryncie, diakonisa Febe, której prawdopodobnie zlecił misję przekazania wspólnocie w Rzymie swojego listu, Lidia, która służyła mu gościnnością swego domu. Należy zauważyć, że Lidia samodzielnie utrzymywała swój dom, była kobietą niezależną finansowo. Święty Łukasz wspomina, że „[k]iedy została ochrzczona razem ze swym domem, zwróciła się z prośbą: «Jeżeli uważacie mnie za wierną Panu, przyjdźcie do mego domu i zamieszkajcie w nim». I wymogła to na nas" (Dz 16,15). Jakże otwarta była pierwotna wspólnota chrześcijańska na posługę kobiet, skoro męskie grono ewangelizacyjne mogło swobodnie mieszkać w domu, którym zarządzała kobieta. Paweł, przebywając w Koryncie, zamieszkał w domu Pryscylli i Akwili i razem z nimi pracował, ponieważ jako były faryzeusz zdobył umiejętność pracy fizycznej. Gdy do Efezu przybył Apollos, to Pryscylla i Akwila wyłożyli mu dokładnie drogę Bożą, a więc to oni stali na straży depozytu wiary ${ }^{75}$. Niestety wpływy kultury grecko-rzymskiej ograniczyły w następnych wiekach znaczenie kobiet $w$ posłudze ewangelizacyjnej ${ }^{76}$. Czas zatem przywrócić ich rolę w posłudze ewangelizacyjnej Kościoła! Wszakże matka pochylająca się nad dzieckiem i składająca mu po raz pierwszy rączki do modlitwy jest pierwszą osobą otwierającą je na świat nadprzyrodzony!

\section{Konkluzja}

Warto zauważyć, że kobiety w Izraelu odgrywały znaczącą rolę w życiu społecznym i miały olbrzymi wpływ na wychowanie dzieci.

75 Por. D. Marzotto, Piotr i Magdalena, s. 93-103.

76 Por. J. Koleff-Pracka, Kobieta, w: Encyklopedia PWN, t. 5: Religia, Warszawa 2002, s. 483n. 
Hellenizacja społeczeństwa Izraela negatywnie wpływała na pozycję kobiety ${ }^{77}$. Obraz kobiet zamkniętych $\mathrm{w}$ odosobnieniu w ramach domowego środowiska, charakterystyczny dla świata hellenistycznego, został zaaprobowany w judaizmie ${ }^{78}$. W komentarzu żydowskim do Księgi Rodzaju czytamy: „gdyby Bóg chciał, aby kobieta włóczyła się po dworze, stworzyłby ją ze stopy Adama, a nie z jego żebra" (Gen. R. 18,2) ${ }^{79}$.

W Talmudzie znajdziemy wiele kąśliwych wypowiedzi rabinów pod adresem kobiet, ale są też piękne, ukazujące ich wartość. Nauczycielowi św. Pawła, Gamalielowi, przypisywana jest następująca opowieść: „Pewien cesarz rzekł do mędrca: Twój Bóg jest złodziejem. By stworzyć niewiastę, musiał uśpionemu Adamowi ukraść żebro. Gdy zakłopotany mędrzec nie wiedział, co odpowiedzieć, córka rzekła mu: Pozwól, abym załatwiła to sama. Poszła tedy do cesarza i oświadczyła mu: Zanosimy skargę. Tej nocy złodzieje dostali się do naszego domu i skradli srebrną konewkę, zostawiając zamiast niej złotą. Szkoda, że nie mam co noc podobnych odwiedzin - wykrzyknął, śmiejąc się cesarz. To właśnie uczynił nasz Bóg: zabrał pierwszemu człowiekowi zwykłe żebro, a w zamian za to dał mu niewiastę"80.

Koncepcja samodzielnej kobiety egzystującej poza kontekstem domowym pojawiła się w społecznej strukturze Rzymu dopiero wraz z powstaniem chrześcijaństwa i propagowaniem życia kobiety w celibacie ${ }^{81}$. Warto zauważyć, że Akwila i Pryscylla, jedni z pierwszych chrześcijan, wspólnie prowadzili dom i zajmowali się wytwarzaniem namiotów (por. Dz 18,1-4). W trzech

77 Por. S.A. White, Kobiety, w: Stownik wiedzy biblijnej, s. 308.

78 Por. D.F. Sawyer, Kobiety i religie w poczatkach naszej ery, tłum. K. Ciekot, Wrocław 1999, s. 120.

79 Tamże, s. 58; por. Ze skarbnicy Midraszy, tłum. M. Friedman, Wrocław 1995, s. 10.

80 Por. M. Rosik, Kobieta w życiu religijnym starożytnej Palestyny, w: Kobiety w czasach biblijnych, red. I. Skupińska-Løvset, P. Machałowska, Łódź 2008, s. 77n.

81 Por. D.F. Sawyer, Kobiety i religie w poczq̨tkach naszej ery, s. 33. 
kolejnych wzmiankach o tej parze imię Pryscylli wymienia się przed imieniem jej męża (por. Dz 18,18; Rz 16,3; 2 Tm 4,19).

W Nowym Testamencie pojawia się wiele kobiet. W rodowodzie Jezusa, przedstawionym przez ewangelistę Mateusza, wymienia się cztery znaczące ich postacie wraz z piątą Maryją, która wieńczy Stary Testament i otwiera nową rzeczywistość zbawienia. Ewangelista Jan ukazuje Samarytankę jako wzór kobiety niosącej Dobrą Nowinę o Jezusie. Marii Magdalenie zostanie powierzona prawda o zmartwychwstaniu Jezusa, a Maryja poprzez swoją zgodę na wypełnienie woli Bożej stanie się przedstawicielką całej ludzkości przed Bożym obliczem. Wielkie zmiany dotyczące znaczenia kobiet w życiu publicznym i religijnym, jakie dokonały się w kręgu kultury śródziemnomorskiej w momencie wkroczenia na arenę dziejów chrześcijaństwa, ciągle wymagają przemyśleń i aktualizacji.

\section{Women in the "school" of Jesus and the after Passover community and their different models of life and commitment to evangelization}

Jesus gathered a community of disciples around himself from which he chose the circle of Twelve. However, women who played a significant role in the paths of evangelization were also part of his nearest environment. Nevertheless, including them in the process of evangelization required overcoming many cultural, social and religious barriers. Even in Jesus' bloodline - depicted by Matthew, the Evangelist - four significant women with the fifth, Mary, who crowns the Old Testament and opens a new reality of salvation, are mentioned. Mary becomes a new representative of the entire humanity before the face of God through her agreement to fill God's will. John the Evangelist depicts a Samaritan as an example of a woman bringing Gospel of Jesus. She becomes a model figure who enters the path of faith earlier than 
the circle of men, moreover, she evangelizes a community dominated by men. based on the example of the relations of Jesus with the family of Martha, Mary and Lazarus we receive a lesson of love. Jesus says that only one matter is needed! What? That is mutual love because only with it we open our hearts to His word. This love is being spoken of by sisters when they inform Jesus: "Lord, the man you love (Greek: phileo) is ill." (John 11:3). The Evangelist adds that "Jesus loved (Greek: agapao) Martha and her sister and Lazarus" Now Jesus loved Martha, and her sister, and Lazarus." The Greek language allowed the Evangelist to present different shades of love in which this feeling towards Lazarus and the entire community was manifested. His relationship with Lazarus is based on friendship which was deemed by Greeks to be the deepest interpersonal relation and love in a community is based on mutual support and bestowment of good. Jesus is not ashamed of his love toward Lazarus! He shows his suffering caused by a loss of a friend with crying (John 11:35) and the gathered Jews said the following significant words: "See how much he loved (Greek: philo) him!". An example of love which will be the basis for evangelization is the figure of Mary Magdalene who will be called the Apostle of Apostles. It is love that mobilizes Mary Magdalene to go out to Jesus' grave early in the morning when it was still dark (John 20:1). Based on this love, similarly to Peter (John 21), Mary Magdalene would be entrusted with the truth about Jesus' resurrection. Great changes regarding the significance of women in public and religious life which took place in the realm of Mediterranean culture at the time when Christianity entered the arena of history still require consideration and actualization. 